\title{
Inhaltsverzeichnis / Table of Contents
}

I Einleitung / Introduction

Daniel Jacob

Sprach- und Literaturwissenschaft: Zuständigkeiten und Begegnungen -3

II Disziplinen, Institutionen, Diskurse / Disciplinary Differences, Institutional Settings and their Discourses

Jörg Schönert

„Liaisons négligées“. Zur Interaktion von Literaturwissenschaft und Linguistik in den disziplinären Entwicklungen seit den 1960er Jahren — 37

Rolf Kailuweit und Ana Renault Inda

Vom Übersprung des Zeichens: Jacques Derridas Husserllektüre zwischen Sprach- und Literaturtheorie -67

III Vom Sprechakt zum Text: Illokution, Referenz und Inferenz / From Speech Acts to the Text: Illocution, Reference, and Inference

Andreas Kablitz

Referenz und Fiktion -93

Roger D. Sell

A Communicational Criticism for Post-postmodern Times — 127

Paul J. Hopper

A Narrative Anomaly in Josephus: Jewish Antiquities xviii:63 147

Eva von Contzen

Saints' Lives as Narrative Art? Towards a Pragma-Narratological Approach to the Scottish Legendary — 171

Wulf Oesterreicher

Referenz, Diskurstraditionen und Handlungsfelder im Rahmen einer sozialen Semiotik: Die Linguistik und ihre Nachbarn — 199 
IV Stil - Varietät - Perspektive / Stylistics - Language Varieties Perspectives of Presentation

\section{Dan Shen}

Defending the Validity of Stylistics and Trying to Make it More Helpful to Literary Interpretation 237

Ben Rampton

An Everyday Poetics of Class and Ethnicity: Stylisation and Crossing -261

\section{Elena Semino}

Language, Mind and Autism in Mark Haddon's The Curious Incident of the Dog in the Night-Time — 279

V Gattungen zwischen Produktion und Wahrnehmung / Genres: Patterns of Text Production and Perception

Susanne Günthner

Discourse Genres in Linguistics: The Concept of

'Communicative Genres' — 307

Angelika Linke

Genre und Lebenswelt: Zur kulturgeschichtlichen Zeichenhaftigkeit von Genres und ihrer historischen Veränderung — 333

Wolfgang Raible

Medium and Genre 359

Ralf Schneider and Marcus Hartner

The Cognitive Theory of Literary Genres Revisited: Cues from Construction Grammar and Conceptual Integration -385

Klaus W. Hempfer

Some Aspects of a Theory of Genre — 405 


\section{Abschließende Bemerkungen / Epilogue}

Monika Fludernik

Closing Statement: Revisiting Jakobson _ 425

Zu den Autoren / About the Contributors - 445 
